\title{
UNIVERSITYOF
}

FORWARD

THINKING

WESTMINSTER用

WestminsterResearch

http://www.westminster.ac.uk/westminsterresearch

Airport Competition with the Scottish Lowlands Region

Pagliari, R. and Graham, A.

NOTICE: this is the authors' version of a work that was accepted for publication in Research in Transportation Economics. Changes resulting from the publishing process, such as peer review, editing, corrections, structural formatting, and other quality control mechanisms may not be reflected in this document. Changes may have been made to this work since it was submitted for publication. A definitive version was subsequently published in Research in Transportation Economics, DOI: 10.1016/j.retrec.2019.100760, 2019.

The final definitive version in Research in Transportation Economics is available online at:

https://dx.doi.org/10.1016/j.retrec.2019.100760

(c) 2019. This manuscript version is made available under the CC-BY-NC-ND 4.0 license https://creativecommons.org/licenses/by-nc-nd/4.0/

The WestminsterResearch online digital archive at the University of Westminster aims to make the research output of the University available to a wider audience. Copyright and Moral Rights remain with the authors and/or copyright owners.

Whilst further distribution of specific materials from within this archive is forbidden, you may freely distribute the URL of WestminsterResearch: (http://westminsterresearch.wmin.ac.uk/)).

In case of abuse or copyright appearing without permission e-mail repository@westminster.ac.uk 


\section{AIRPORT COMPETITION WITHIN THE SCOTTISH LOWLANDS REGION}

\section{Abstract}

The aim of this paper is to undertake an assessment of airport competition within the Scottish Lowlands region, which has experienced significant variations in economic development, and to examine whether competitive forces have been strengthening or weakening in recent years. This region covers the airports of Edinburgh, Glasgow and Prestwick in the last twelve years they have all experienced changes in ownership. BAA which had, for many years, operated both Edinburgh and Glasgow airports, sold the former to GIP in 2012 whilst in 2013 the Scottish Government purchased the privately-owned Prestwick. During this period there were also significant changes in airline network strategies. In order to assess the competitive pressures facing these airports, three key areas are considered, namely: aeronautical charging policy, the service quality provided and traffic development. The analysis shows that since ownership separation, competition has intensified between Edinburgh and Glasgow, whilst Prestwick airport, which benefitted from Ryanair expansion in the 1990s, is now a significantly diminished competitive proposition in the Scottish Lowland market. This has implications not only for airport policy and economic regulation but also for broader economic well-being in this region.

\section{Key words}

Scottish airports, airport competition, aeronautical charges, route development

\section{JEL classification}

\section{L43 R41 R49}

\section{Introduction}

The Scottish Lowlands region in the UK with a total population of around five million citizens is served by three main airports: Edinburgh, Glasgow and Prestwick. Edinburgh is the largest of the three, serving 14.3 million passengers in 2018, compared to 9.7 million at Glasgow and only 0.7 million at Prestwick. Edinburgh and Glasgow airports are separated by a distance of $77 \mathrm{~km}$, connected by the M8 motorway which links their respective metropolitan areas, with populations of around 450,000 and 600,000 respectively. Prestwick also serves the Glasgow metropolitan region. However, Glasgow airport is much closer to the main population catchment area as it is located in Paisley which is only $15 \mathrm{~km}$ from the City Centre. In contrast, 
despite having a direct rail connection to Glasgow city centre, Prestwick is disadvantaged by its location, sited approximately $64 \mathrm{~km}$ to the south of its nearest competitor (see Figure 1).

\section{Figure 1: $\quad$ Map of Lowland Scotland}

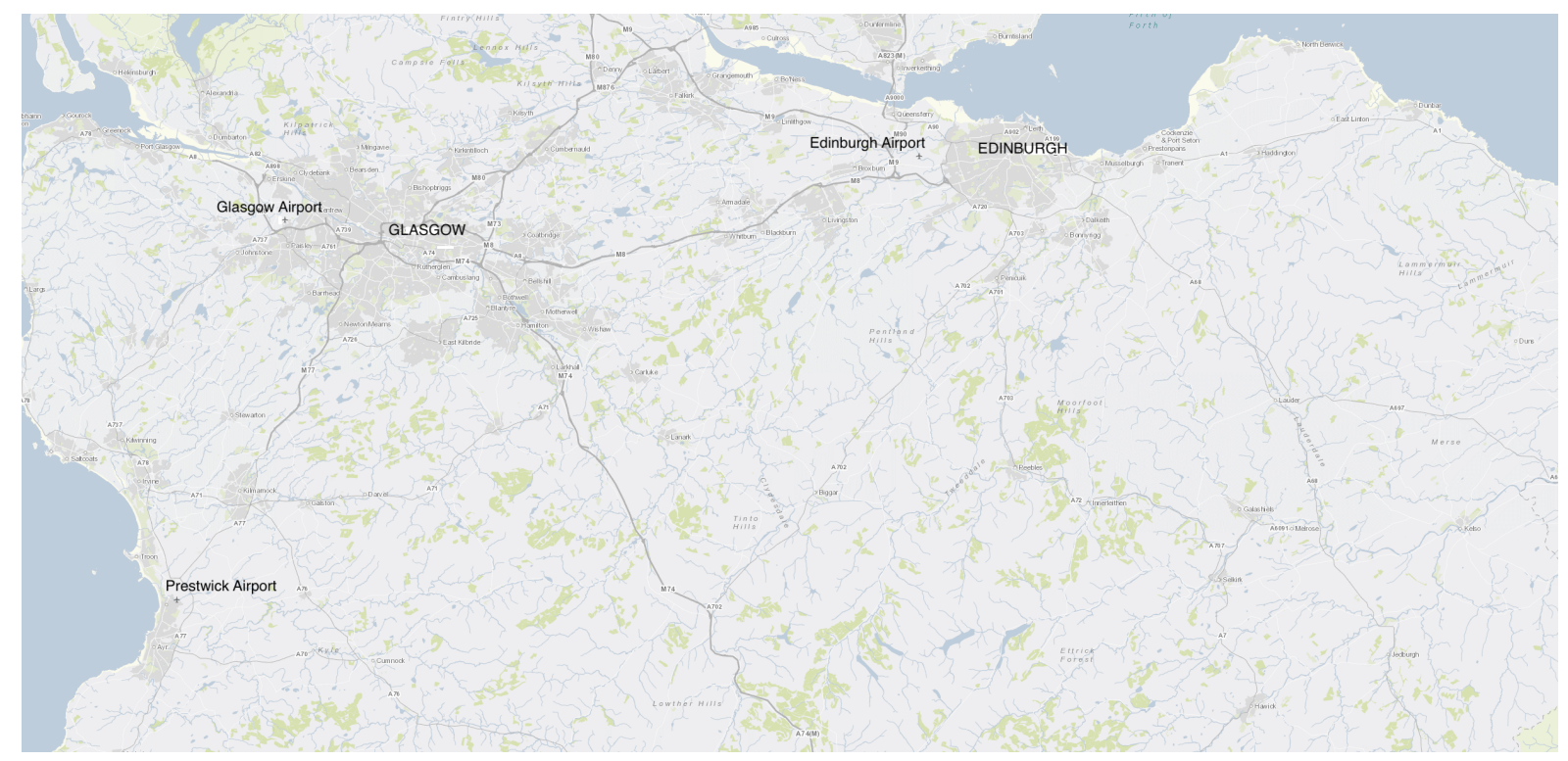

Source: adapted from ArcGIS

Historically Prestwick was a very important airport for the region, as traffic distribution rules and air service bilateral agreements ensured that it had exclusive rights as the only gateway for transatlantic scheduled flights from Scotland. When these restrictions were removed in 1990, transatlantic airlines switched their operations to Glasgow ensuring that it emerged and remained the preferred Scottish gateway for international services during the 1990s. The establishment of the Scottish Parliament in Edinburgh in 1999 and the growth of its financial services sector provided the extra stimulus behind a sustained and robust period of traffic growth post-2000 to such an extent that by 2007 , it eclipsed Glasgow to become the busiest airport in Scotland.

Since 2007, there have been a number of important developments affecting the three airports. In 2008 the financial crisis and global economic recession had a significant impact on airport traffic levels across the world. During this period in the UK and more specifically in Scotland there were also significant developments in airport ownership. Both airports were incorporated into the state-owned British Airports Authority (BAA) during the 1970s. Joint ownership continued when the BAA was privatised in 1987. However, in 2009, the former UK competition authority (the Competition Commission) following an investigation, had concluded that such 
common ownership had given rise to adverse effects on competition and subsequently BAA was forced to sell Edinburgh in 2012. This was followed by BAA's successor entity, Heathrow Airports Holding's (HAH), disposal of Glasgow in 2014. The ownership of Prestwick evolved differently. Whilst originally part of the BAA group when it was privatised in 1987, it was subsequently acquired by a number of different private owners. However, a recent decline in traffic and financial problems led to the airport being re-nationalised by the Scottish Government in 2013.

During this period of ownership change, other significant developments had been occurring within the European air transport environment. Airline and airport competition intensified, especially with the emergence of the low cost carrier (LCC) sector. In more recent years, the strategies of these LCCs, and the competing full service carriers (FSCs) and charter airlines have further evolved, having a major impact on the airports, including the Scottish ones, that they serve.

In light of changes in airport ownership and in the evolution of airline competitive strategies, there is a case for trying to understand how these developments have impacted on the nature of airport competition within the Scottish Lowlands region as this has implications for future airport ownership, economic regulation and other policies. Moreover whilst quantifying the exact link between airport growth and broader economic development remains problematic, it is widely acknowledged that this can be a positive relationship. Within this context, the Scottish Lowlands area is particularly interesting as it has experienced significant upturns and downturns in economic prosperity in recent years, particularly with Edinburgh's situation improving after the establishment of the Scottish Parliament in 1998, and Glasgow's declining with the deterioration of surrounding heavy industries and manufacturing activities.

The nature of airport competition needs to be investigated not only through gauging the actual degree of airport competition but also in determining whether there has been a strengthening or weakening of competitive forces through time. In order to undertake this research, three key performance areas have been considered: the level/structure of airport charges, service quality and the development of traffic and routes from 2006 to the present day.

The structure of this paper is as follows. The next section provides the background context by presenting a literature review related to airport competition and the UK 
airport industry. This is followed by an identification of the performance metrics used and the data sources. The analysis is presented in Section 4 and Section 5 provides a general discussion that reflects on the analysis. Section 6 draws concluding comments.

\section{Background literature review covering airport competition and UK airports}

\subsection{Airport competition}

Airport competition has become an area of increasing interest within the research literature with many relevant and diverse issues being explored. Indeed Forsyth at al. (2010) produced the first book devoted to airport competition consisting of 26 chapters covering areas such as competition strength, traveller choice and policy decisions. Elsewhere Barrett (2000) looked at competition between primary and secondary airports and LCCs, Graham (2006) considered competition within airports (e.g. with services and terminals) versus between airports, and Socorro et al. (2018) focused on airport and airline market power and the impact of airline nationality.

Overall, key driving forces of airport competition are increased liberalisation and deregulation which has presented airlines with much more freedom to operate from airports of their choice. This has provided airports with an opportunity to compete for traffic. The more liberal environment has also led to the emergence of new airline business models, most notably LCCs, which have proved to be challenging and somewhat footloose airline customers for airports as they seek to attract and maintain air services (Bush and Starkie; 2014; Gillen and Lall, 2004; Graham, 2013; Humphreys et al., 2006).

The competitive opportunities afforded by deregulation have had a transformative effect on airport business models. Many airports have matured into commercially sophisticated organisations developing a wide range of business development competencies most notably in marketing, route development and in delivering service quality. Increasing privatisation of airports has reinforced the need to pursue such commercially-orientated strategies. Moreover, the increasing adoption of privatisation, concerns with regard to airport market power and developing appropriate frameworks of economic regulation, has prompted more discussion around the extent to which airport markets are truly competitive. If the existence of competition does not appear to be sufficient, appropriate and alternative methods of 
economic regulation have been discussed and implemented, in order to substitute for competition and protect users against the potential abuse of market power (Bel and Fageda, 2013; Forsyth, 2006; Starkie, 2012).

There is a lack of agreement in the literature as to the degree to which competitive rivalry exists in the airport industry. Reports commissioned by Airports Council International $(\mathrm{ACl})$ Europe, in advancing the commercial interests of its membership, favour light-handed regulation and they have presented evidence of a relatively high level of competition in airport markets (ACl-Europe, 2014; ACl-Europe, 2017; Oxera, 2017; Thelle et al., 2012). Thelle and la Cour (2018) have supported these arguments, calling for competition constraints associated with economic regulation to be relaxed. Meanwhile, certain airlines and the International Air Transport Association (IATA) have argued vehemently against these opinions (e.g. IATA, 2013). Wiltshire (2018), in support of the airline position, challenged ACl's arguments, claiming that competition is limited in the airport sector and therefore there is a continuing need for robust economic regulation. Lieshout et al. (2016) argued that airport (and airline) competition in fact varies within Europe, being strongest in the UK, Benelux, Western Germany, Switzerland and Northern Italy. It is often with regional airports where the competitive forces can be particularly strong due to the existence of shared catchment areas, providing both airlines and passengers with the ability to choose between different local airports. This is very relevant for the Scottish airport case here.

An indication of the airport competitive environment can arguably be detected through the charging policy of airports and aeronautical pricing (Bottasso et al., 2017). Indeed LeighFisher (2012) identified the extent to which competition is available, as well as the mix of airlines and routes served, as key drivers for airport charges and aeronautical revenue differentiation. Competitive pressures could well drive down prices and produce declining airport yields. There is evidence in both the US (Van Dender, 2007) and in Europe (Bel and Fageda, 2010) of lower aeronautical charging when airports face competition from neighbouring airports. Moreover, increased competition between airports has led to the widespread adoption of incentives offered for new or expanded services and sometimes bespoke agreements or contracts between airports and individual airlines (Halpern and Graham, 2016), one of the numerous examples being in Poland (Huderek-Glapska and Nowak, 2016). Such deviation from standard airport published charges is becoming increasingly common in Europe (Fichert, 2019; Jones et al, 2013; Malina 
et al, 2012). In fact, Jankovic declared that $90 \%$ of all members of ACl-Europe offered some sort of discount, whilst in the US, Ryerson (2016) in a study of 70 airports, found that incentives were offered by $63 \%$ of them.

Another indication of airport market competitive intensity is through the growing focus on service quality improvement as it can be argued that rival airports will deploy additional effort and resources in improving facilities and process efficiency in order to attract more airlines and passengers (OECD, 2014). Whilst the literature in this area is relatively scarce, Prentice and Kadan (2019) recently found that airport service quality was significantly related to airport reuse, while Kim et al (2016) observed a positive link between passenger satisfaction and airport reuse.

Clearly the success of airports to compete will also be reflected in their traffic development. Strong growth in traffic can indicate airport rivalry in seeking to encourage airlines to establish new services or expand existing networks and their passengers to fly more frequently. New airlines and new routes can provide passengers with more airport choice. Moreover route churn which may involve passengers or airlines switching between different airports, or airlines exiting routes or abandoning airports entirely, can help demonstrate the true substitutability of competing airports. Indeed, in relation to route churn, Thelle at al. (2012) found that in 2011 around 2,500 new routes were launched in Europe compared 2,000 closures and every year around 20 per cent of the total were route openings compared to 15 per cent closures. Route churn, particularly in relation to LCCs was also observed to be intensifying in Europe by De Wit (2016). An analysis of traffic shifts within airport catchment areas can additionally help to assess the competitive forces that exist (Pantazis and Liefner, 2006; Lieshout, 2012) by giving more insight into passenger choice factors.

Further understanding is also provided by looking at airport competition from the users' (e.g. airlines, passengers) rather than airport perspective, and in particular by looking at airport choice factors. For example Dziedzi and Warnock-Smith (2016) found that the most important factors influencing LCC choice of airport were airport costs, demand and catchment area, and efficient operations. These can be linked to the discussion above concerning charges, traffic development and service quality. For passengers airport choice is that much more complicated as for passengers, clearly the nature of air services on offer (in terms of fares, destinations, schedules 
and so on) - in effect the airline product - will be the key influencing factor as no -one will choose to fly from an airport unless it offers the required travel opportunities. However factors including: distance, cost and ease of surface access to a certain airport, as well as cost and convenience of car parking at the airport, can also be very important to passengers. Research consistently shows that the nature of air services and airport accessibility are the key choice factors (CAA, 2011; Mohammed and Roisman, 2017). More complex research has used discrete choice models to understand combined choices related to airlines, airports and surface access (Hess et al., 2007; Garrow, 2010).

\subsection{The UK airport market}

The UK airport industry was the first in the world experience the privatisation process when it passed the 1986 Airports Act (Humphreys, 1999). In 1987, the then British Airports Authority which owned London Heathrow, London Gatwick, London Stansted, Edinburgh, Glasgow, Prestwick and Aberdeen was floated on the London stock exchange as a single entity to become the fully-privately owned company BAA. The legislation also required that all local municipal-owned regional airports generating over $£ 1$ million in annual turnover, were to be managed as limited liability companies. This in essence was the first step in their transition to privatisation. In the following 25 years all the main regional airports became either fully or partially privately operated (although two have also returned to public ownership). This, in combination with the overall growth of traffic, particularly due to liberalisation and the development of the LCC sector, has generally meant that regional airports have become accustomed to operating in a more commercial and competitive environment (Starkie, 2008; Ison et al. 2011).

With regards to BAA, there was considerable debate prior to it being privatised as to whether the airports should have been sold individually or collectively as a group (Littlechild, 2018). Arguments in favour of collective privatisation included the potential advantages that stem from economies of scale, financial robustness through the size and diversity of the asset portfolio and the sharing of technical and managerial expertise across the network. Arguments against collective privatisation tended to focus on the potential loss of the benefits that could have been accrued from airport competition (Graham, 2009; Toms 2004). In spite of a series of UK 
Government reviews which re-visited these arguments, BAA's quasi-monopoly continued unchallenged until 2009. Commercial interest and expediency rather than competition policy prompted the sale of Prestwick in 1992 to the Canadian entrepreneur Matthew Hudson following the loss of transatlantic airline operations to Glasgow. The airport consequently experienced a sharp decline in traffic before a renaissance was engineered by Hudson following the establishment and subsequent expansion of a Ryanair base in the mid-1990s. Prestwick was sold on to the Scottish transport operator Stagecoach in 1998 and then to Infratil, the New Zealand infrastructure investment company, in 2001.

However, the major turning point for BAA was in 2009 when after another review of its market power, the Competition Commission (now known as Competition and Markets Authority (CMA)) concluded that its common ownership of airports in the South-East of England and Scotland was detrimental to competition (Competition Commission, 2009; Bush 2009). As a consequence, BAA was ordered to sell Gatwick (sold in 2009), Stansted (sold in 2013) and Edinburgh or Glasgow (Edinburgh sold in 2012). In 2016, the CMA, with the help of its consultants ICF, undertook a detailed assessment of the effects of the airport divestments (CMA 2016; ICF 2016). The report was able to identify a number of factors that suggested that competitive rivalry had intensified since divestment, manifested in changes to the structure of aeronautical charges, improvements in service quality (observed at Gatwick and expected at Stansted/Edinburgh) and greater passenger growth compared other airports following the adoption of more intensive efforts to attract new airlines.

Meanwhile, Infratil decided to sell Prestwick Airport in 2012 owing to its deteriorating commercial and financial performance largely as a consequence of Ryanair's decision to transfer a significant volume of its operations to Glasgow. Fearing the potential wider economic and employment consequences of closure, it was bought by the Scottish Government for a nominal price of $£ 1$ in November 2013 (Auditor General, 2015). HAH (BAA's successor entity) the owner of the rump of airports that had not been divested, took a decision to focus on its core asset Heathrow and subsequently sold off its remaining airports including Glasgow in 2014. Ownership of Glasgow, as well as the other HAH Scottish airport Aberdeen was transferred to AGS, with $50 \%$ being owned by Ferrovial which also had a significant shareholding (25\%) in HAH (BBC, 2014). 
In parallel to these changes in ownership, there were also important developments in relation to traffic growth, the evolution of LCCs operations and shifts in airline and airport strategies, and this has been subject to some interesting research (e.g. Civil Aviation Authority (CAA), 2005, 2007; Papatheodorou and Lei, 2006; Halpern et al. 2016; Lei and Pagliari, 2013, Halpern and Graham, 2017). It is clear from this evidence base that the operating and competitive environment for each individual regional UK airport had varied enormously and as a result, their performance and achievements through time had been very different. However, there has been very little detailed consideration of the Scottish airports, except the contribution by Pagliari (2005) on international route development. Therefore, this paper goes some way in addressing the literature gap.

\section{Choice of Performance Metrics}

Buildling on the literature review, an analysis of aeronautical charging, service quality performance and traffic development has been chosen to assess the extent and development of competition within the Scottish Lowlands region. Key performance metrics for these areas (traffic development has been divided into traffic growth, route development and catchment area analysis) have been defined in Table 1 and accompanied by the data sources used. The metrics focus very much on the airport's perspective of competition, and so are very similar to those adopted in the studies of ICF (2016) and CMA (2016), rather than looking at broader issues related to airline and passenger choice factors that were also mentioned in the literature review.

\section{Table 1: $\quad$ Analysis areas and data sources}

\begin{tabular}{lll}
\hline Analysis areas 2006-2018/(financial values in real terms) & Data sources \\
\hline $\begin{array}{l}\text { Aeronautical charging: } \\
\text { Turnaround airport charges } \\
\text { Landing charges } \\
\text { International and domestic passenger charges } \\
\text { Aeronautical revenue per passenger/aircraft movement }\end{array}$ & $\begin{array}{l}\text { Published airport charges } \\
\text { from } \begin{array}{l}\text { airport's } \\
\text { the }\end{array} \\
\text { websites, airport annual } \\
\text { reports }\end{array}$ \\
\hline $\begin{array}{l}\text { Service quality performance: } \\
\text { Which? travel passenger satisfaction scores }\end{array}$ & $\begin{array}{l}\text { Airport annual reports, ICF } \\
\text { (2016), Which? UK airport } \\
\text { reports (as published in the } \\
\text { Which? Travel Magazine) }\end{array}$ \\
\hline $\begin{array}{l}\text { Traffic growth: } \\
\text { Total, domestic, EU and non-EU passenger growth, market share }\end{array}$ & CAA airport statistics \\
\hline
\end{tabular}


For aeronautical charging, initially all charges incurred on an aircraft turnaround are considered. This is very much influenced by landing and passenger charges, which account for the majority of aeronautical revenues, and so these are also investigated separately. However these measures only show the published airport charges and not the discounts and incentives that airports are increasingly offering. An assessment of actual aeronautical revenue per passenger/aircraft movement, as frequently used in airport economic performance literature, was used to measure this.

As regards service quality, it is difficult for researchers to obtain sufficient data and insights on service quality at different airports. Data and performance metrics remain largely proprietary. The online customer service ratings platform Skytrax is accessible, but the sample size of customers submitting their views at the three Scottish airports is small and varies considerably. Indeed, it is doubtful whether Skytrax can be considered as a reliable source given the greater degree of subjectivity and bias in the data. Some limited evidence can, however, be accessed from the surveys of ACl ASQ and Which?. The ASQ is arguably the most wellknown, extensive and dependable source, but only the airports themselves have access to most of the data. The Which? data is a useful source that is not often used in academic research and so provides additional insight. Which? is a reliable and well established consumer organisation, with a sample size of over 11,000, albeit that their survey samples are only made up of Which? subscribers (Which?, 2019a; 2019b). The CAA has also begun to publish passenger experience ratings from their airport surveys but this has only been for the last two years.

Traffic development data which is more consistent and more easily accessible was used to provide both a demand and supply perspective of the issue. Passenger numbers, split by key markets, show the nature of demand, whereas the route development metrics provide the supply view. These measures have been widely used in similar research, whereas the catchment area analysis, which links traffic 
generation to the surrounding areas, is unusual as the CAA data is a rare case when such data is freely available and based on reliable, extensive surveys.

For most of the analysis the time series of 2006-2018 was chosen. This 13 year dataset was considered to be long enough to assess the impact of recent changes that have been occurring. 2006 was chosen specifically to provide two comparatively 'normal' years before the global recession. Moreover since major ownership changes occurred in 2012-2013, the time series selected provides a balanced view of the situation before and after these developments.

\section{Analysis}

\subsection{Aeronautical charging}

The first part of the analysis involves a comparison of the aeronautical charges levied at the three Scottish airports (Table 2). Comparative charges levels are assessed by aggregating the individual charges that are levied for a given aircraft turnaround operation (arrival and departure) based on fixed assumptions relating to aircraft type, passenger load factor, parking time and the number of bags. This approach is known as the turnaround cost method as it sums all the charges that are incurred in an aircraft turnaround (landing, on ground, departure). The A320 aircraft has been chosen with an assumed load factor of $85 \%$ and parking time on the stand of 60 minutes as this is fairly typical of the aircraft operations at the airports. It is also assumed that this aircraft arrives from and departs to an international airport in another EU member state.

It is evident that Edinburgh is the most expensive airport, followed by Glasgow and then Prestwick, providing some evidence of price divergence and competitive rivalry between the three airports. The passenger charge is by far the most important in revenue terms, followed by the landing charge and so both of these are given more detailed consideration.

Table 2: $\quad$ Turnaround airport ${ }^{1}$ charges at Edinburgh, Glasgow and Prestwick 2018-2019

\begin{tabular}{lrrr}
\hline & Edinburgh & Glasgow & Prestwick \\
\hline Landing charge & $£ 429.98$ & $£ 416.01$ & $£ 339.57$ \\
\hline
\end{tabular}




\begin{tabular}{lrrr}
\hline Parking charge & $£ 24.99$ & $£ 17.28$ & $£ 0.00$ \\
Passenger charge & $£ 2,425.04$ & $£ 2,053.26$ & $£ 1,666.17$ \\
Terminal navigation charge & $£ 355.01$ & $£ 342.51$ & $£ 226.38$ \\
Persons of Reduced Mobility (PRM) charge & $£ 82.62$ & $£ 80.02$ & - \\
Police and aviation security charge & $£ 61.20$ & - & $£ 336.60$ \\
Baggage hall and screening charges & $£ 113.22$ & $£ 125.46$ & $£ 38.25$ \\
TOTAL & $£ 3,492.05$ & $£ 3,034.24$ & $£ 2,606.97$ \\
\hline
\end{tabular}

1 Based on an A320 (MTOW 73.5), seat capacity 180, load factor $85 \%$ (passengers 153), parking time 60 minutes and 77 hold bags.

Source: Edinburgh, Glasgow and Prestwick airports conditions of use documents 2018-2019.

In Figures 1 and 2 we compare individual landing and passenger charges for Edinburgh and Glasgow over the period 2006 to 2019. Data is not available for Prestwick and would also have been of limited value given that during this period the airport would have negotiated separate charges with Ryanair, its main airline, under a bespoke commercial agreement with the airport. What is particularly interesting is that the charging levels under common ownership were very similar and in real terms there was a marked decline in the published landing fee between 2006 and 2012. This was then followed by a consistent and continuous rise in unit rates at both airports after Edinburgh's sale with a modest level of reduction at Glasgow post-2015 when it was under AGS management.

Figure 2: Landing charge per tonne of MTOW at Edinburgh and Glasgow airports 2006-2018

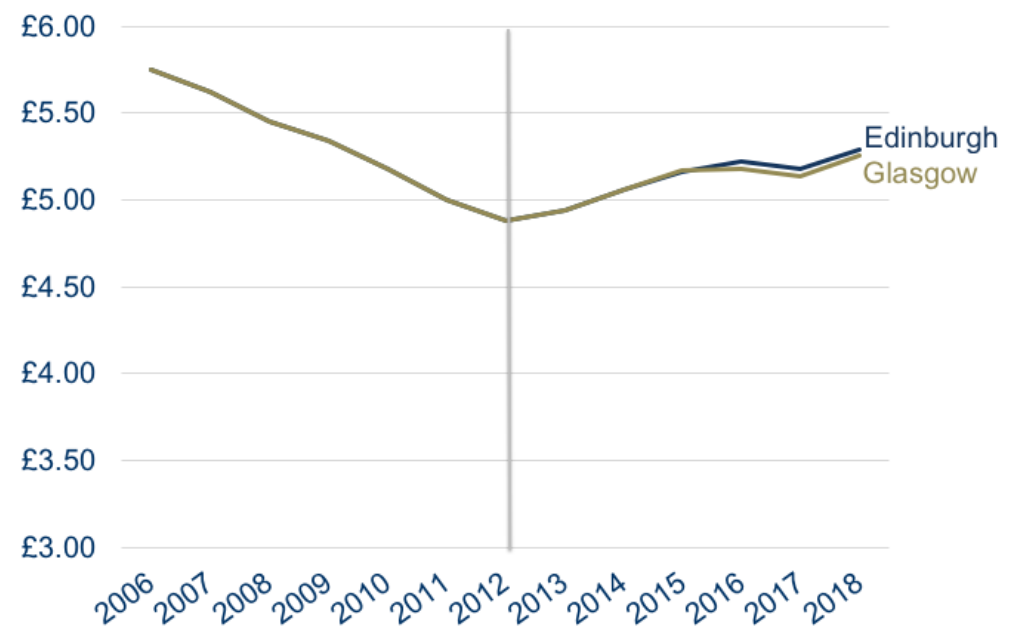

Source: Edinburgh and Glasgow conditions of use documents 2006-2018 
Figure 3 shows that, in contrast to the landing charge, a significant and distinct deviation emerged between the two airports with respect to the trajectory of published per passenger charges.

Figure 3: International and domestic per passenger charge at Edinburgh and Glasgow airport 2006-2018

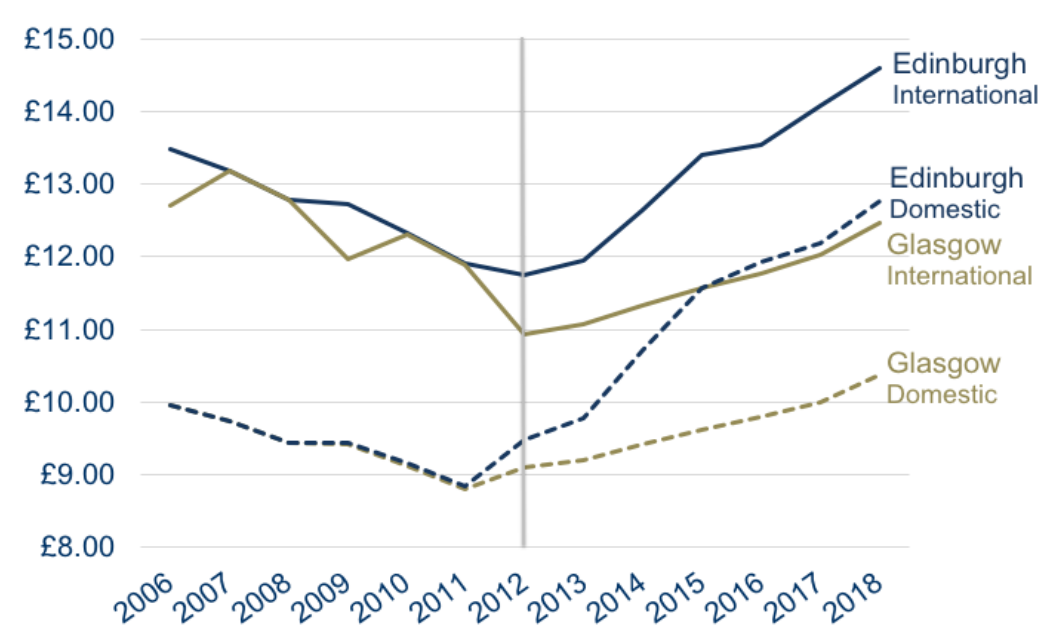

Source: Edinburgh and Glasgow conditions of use documents 2006-2018

Under BAA ownership between 2006 and 2012, charges were fairly similar and as with the landing charge, there were notable real-term reductions. There was, however, a sharper decrease in the international passenger charge at Glasgow in 2009 possibly as a reaction to weaker market conditions following the 2008 financial crisis. Since 2012, charges have not only increased but they also have also diverged substantially, rising at a much faster rate at Edinburgh compared to Glasgow. This is especially with regard to the domestic charge which increased by a factor of $35 \%$ in real terms since 2012 at Edinburgh airport.

As discussed in the literature review, many airlines do not pay the full published rates. Instead, they often negotiate a discount as an incentive offered by the airports to attract new or expand existing air services. They may go even further by entering into longer-term bespoke negotiated agreements with airports that involve a degree of risk-sharing where charges are linked to incentives around the airline's delivery of traffic and capacity. Prestwick has such an agreement with Ryanair and indeed on the airport marketing website 'The Route Shop', the airport states (The Route Shop, 2019): 
'Glasgow Prestwick offers airlines a 'one stop shop' offering with highly competitive deals and packages to include: Landing and navigation, Terminal Infrastructure, Security, Passenger Handling, Aircraft Handling. Charges can be structured on a per departing passenger basis (no MTOW charges) which shares the risk by only charging for passengers onboard. Offering the best deal available within the Scottish market'

Generally incentives that offer no landing charge are popular, because of the identified reduced risk for the airline (but consequently greater risk for the airport). Edinburgh and Glasgow airports also state in their conditions of use documents that they offer incentives, but no details are provided.

As discussed, average aeronautical revenue per traffic unit, otherwise known as aeronautical yield, can take into account these incentives and individual negotiated rates, and so is arguably a more accurate measure of actual price than the published tariffs. This represents the average price that is paid by all operations at an airport by dividing the total aeronautical revenue in a financial year by the volume of traffic units (passengers or air transport movements). However, it is important to recognise that one of the limitations inherent in the yield method is that movement over time will not only reflect alterations in pricing policy but equally shifts in the mix of traffic serving an airport and possible strategies designed to differentiate between routes, airlines and passengers that the airport may wish to attract. The movement of aeronautical yield over time is shown in Figures 4 and 5 . with the former based on passenger volume as the traffic denominator and the latter based on aircraft movements.

Regarding passenger-based yield, Prestwick had to be excluded because of the very different mix of traffic handled by the airport. The airport has historically served the non-regular passenger market. This segment has become especially prominent since 2008 because of the significant decline in passenger-related activity. It would therefore be misleading to compare passenger-based yield with Glasgow and Edinburgh because at those airports, traffic mix had historically remained quite stable with a substantial proportion accounted for by regular scheduled and charter services.

According to Figure 4, passenger yield has followed a broadly similar trajectory to that of the published rates, in that the overall level of charges is higher at Edinburgh, especially after 2012. By contrast, whilst published prices declined in real terms between 2008 and 2010, the aeronautical yield increased at both airports. 
Figure 4: $\quad$ Aeronautical revenues per passenger in real terms at Edinburgh and Glasgow airport 2006-2017

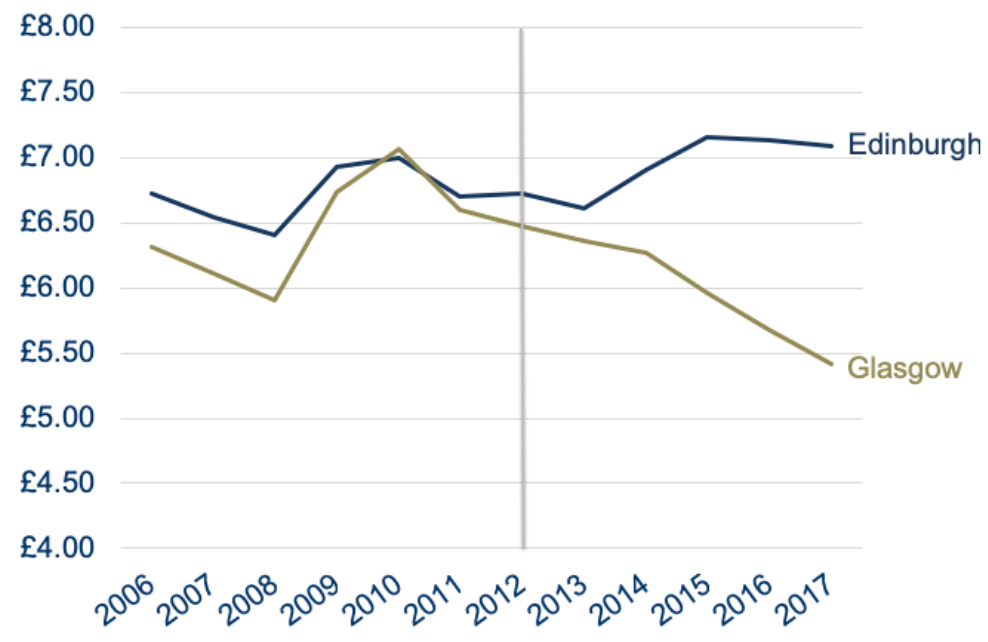

Source: Annual reports and accounts for Edinburgh International Airport Ltd and Glasgow International Airport Ltd

However, this period coincided with reductions in passenger numbers at both airports, which may partly explain the higher aeronautical yield as the dominant passenger charge is directly linked to passenger numbers. Subsequently yields at Edinburgh rose marginally (very broadly going in the same direction as the published charges) whereas the Glasgow yield declined significantly suggesting a much more extensive use of discounts on the published airport charges. Indeed, what is striking is that the gap between both airports in terms of average passenger yield has widened considerably since ownership separation in 2012.

Figure 5: Aeronautical revenues per aircraft movement at Edinburgh, Glasgow and Prestwick airport in real terms 2006-2017 


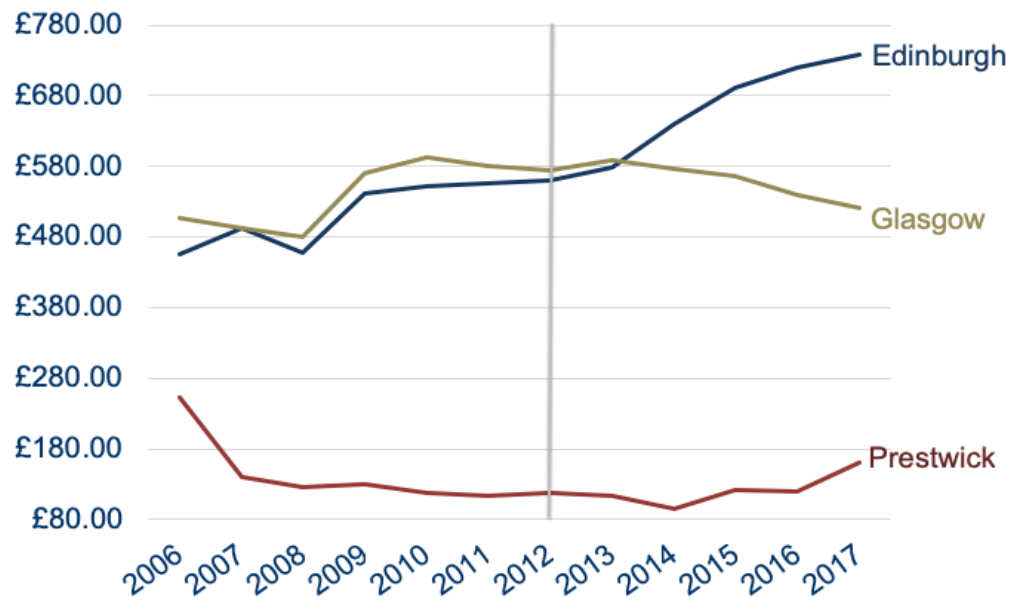

Source: Annual reports and accounts for Edinburgh International Airport Ltd,

Glasgow International Airport Ltd and Prestwick International Airport

2006 to 2017

When aircraft movements is used as the yield denominator, Prestwick is included and what is observed is the considerable gap that has existed with its competitors since 2006 and has become especially more apparent since 2012 .

\subsection{Service quality performance}

Service quality is considered next as it is usually assumed that within competitive markets that there are strong incentives to maintain or enhance service quality. For the ACI ASQ survey, passengers rank their satisfaction from 1 (very poor) to 5 (excellent) and in Table 3, scores out of 5 have been converted into percentages (data before 2010 was not available, nor for Prestwick).

Table 3: $\quad$ Passenger satisfaction measures at Edinburgh, Glasgow and Prestwick airport 2008-2018

\begin{tabular}{|c|c|c|c|c|c|}
\hline \multirow[t]{2}{*}{ Year } & \multicolumn{2}{|c|}{$A C I A S Q$ survey } & \multirow[b]{2}{*}{ Edinburgh } & \multicolumn{2}{|c|}{ Which? travel survey } \\
\hline & Edinburgh & Glasgow & & Glasgow & Prestwick \\
\hline 2008 & $\mathrm{n} / \mathrm{a}$ & $n / a$ & 55 & 50 & 46 \\
\hline 2009 & $\mathrm{n} / \mathrm{a}$ & $\mathrm{n} / \mathrm{a}$ & $\mathrm{n} / \mathrm{a}$ & $\mathrm{n} / \mathrm{a}$ & $\mathrm{n} / \mathrm{a}$ \\
\hline 2010 & 80.0 & 77.2 & $\mathrm{n} / \mathrm{a}$ & $\mathrm{n} / \mathrm{a}$ & $\mathrm{n} / \mathrm{a}$ \\
\hline 2011 & 82.0 & 78.0 & 60 & 54 & 53 \\
\hline 2012 & 83.8 & 79.6 & $\mathrm{n} / \mathrm{a}$ & $\mathrm{n} / \mathrm{a}$ & $\mathrm{n} / \mathrm{a}$ \\
\hline 2013 & 82.0 & 79.2 & $\mathrm{n} / \mathrm{a}$ & $\mathrm{n} / \mathrm{a}$ & $\mathrm{n} / \mathrm{a}$ \\
\hline 2014 & 82.1 & 80.8 & 63 & 57 & 58 \\
\hline 2015 & 85.6 & 82.0 & 63 & 62 & $\mathrm{n} / \mathrm{a}$ \\
\hline 2016 & 85.8 & 81.8 & 59 & 64 & $n / a$ \\
\hline 2017 & 87.2 & 82.0 & 56 & 59 & $\mathrm{n} / \mathrm{a}$ \\
\hline 2018 & $\mathrm{n} / \mathrm{a}$ & $\mathrm{n} / \mathrm{a}$ & 59 & 63 & $\mathrm{n} / \mathrm{a}$ \\
\hline
\end{tabular}

Source: Annual reports and accounts for Edinburgh International Airport Ltd and Glasgow International Airport Ltd 2010 to 2017, ICF (2016), Which? travel UK airport survey 2008 to 2018 
Values at Edinburgh were consistently higher than at Glasgow. Overall at both airports satisfaction rates improved over the period, although Edinburgh experienced a dip in 2013 and 2014. Which? travel also produced scores for the three airports for 2008, 2011 and 2014-2018 (just the early years for Prestwick). Whereas up to 2015 similar observations can be made as with the ACI ASQ results (i.e. scores increasing at Glasgow and Edinburgh, with higher scores at Edinburgh), in the period that follows, trajectories are not so clear, with Glasgow overtaking Edinburgh as the best ranked airport and with some declines as well as improvements in the satisfaction scores. By contrast satisfaction scores obtained by the CAA for 2018, which have not be available for previous years, show Glasgow and Edinburgh having almost identical scores when converted to percentages) of $85 \%$ (CAA, 2019) which further complicates the apparent situation. For the limited years when scores for Prestwick airport are available, satisfaction levels also seem to be improving and in 2011 and 2014 were similar to those at Glasgow airport.

\subsection{Traffic growth}

Figure 6 shows combined terminal passenger volumes at the three Scottish Lowland airports between 2006 and 2018. Overall there has been growth, but the effect of the financial crisis and economic recession in 2008-2010 is clearly apparent. In the latest year 2018, overall traffic grew although there was a slight decline at Glasgow (the first since 2010) and Prestwick.

Figure 6: Terminal passengers at Edinburgh, Glasgow and Prestwick airport 2006-2018

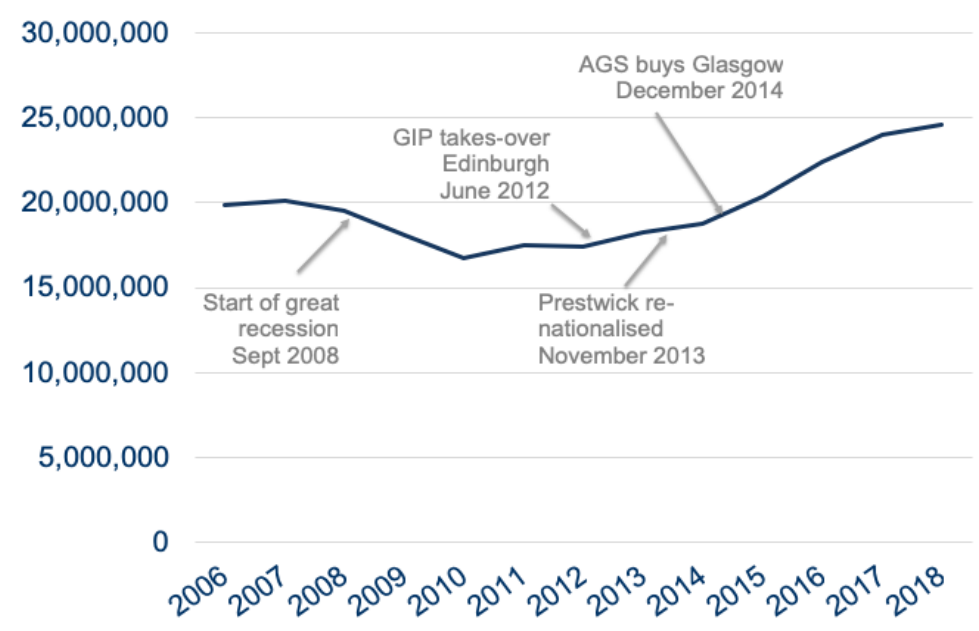

Source: CAA airport statistics 2006-2018 
Figure 7 illustrates very clearly how Edinburgh has increased its market share (43\% to 58\%) - becoming the busiest airport in 2007 - whilst Prestwick's share has declined significantly $(12 \%$ to $3 \%)$, and now only represents a very marginal proportion of the total market. Glasgow's share has declined slightly from $44 \%$ to $39 \%$, seemingly gaining traffic from Prestwick but losing to Edinburgh.

Figure 7: $\quad$ Market share (\%) of Edinburgh, Glasgow and

Prestwick airport 2006-2018

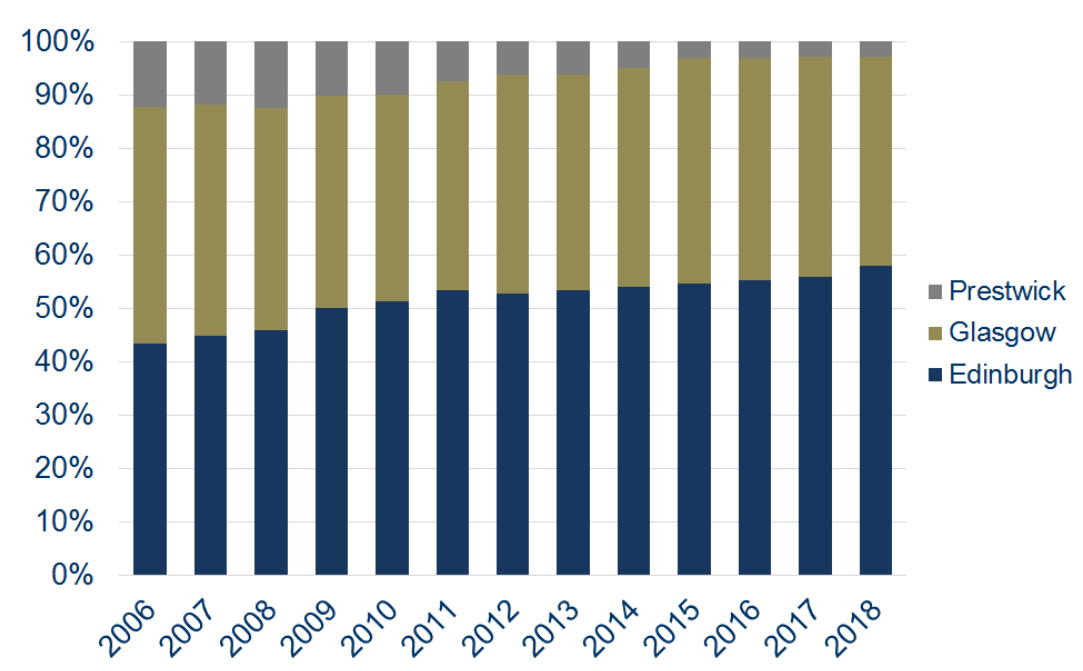

Source: CAA airport statistics 2006-2018

Overall volumes of domestic traffic have declined between 2006 and 2018 and at Prestwick there are no longer any domestic services (Figure 8).

Figure 8: Domestic terminal passengers at Edinburgh, Glasgow and Prestwick airport 2006-2018

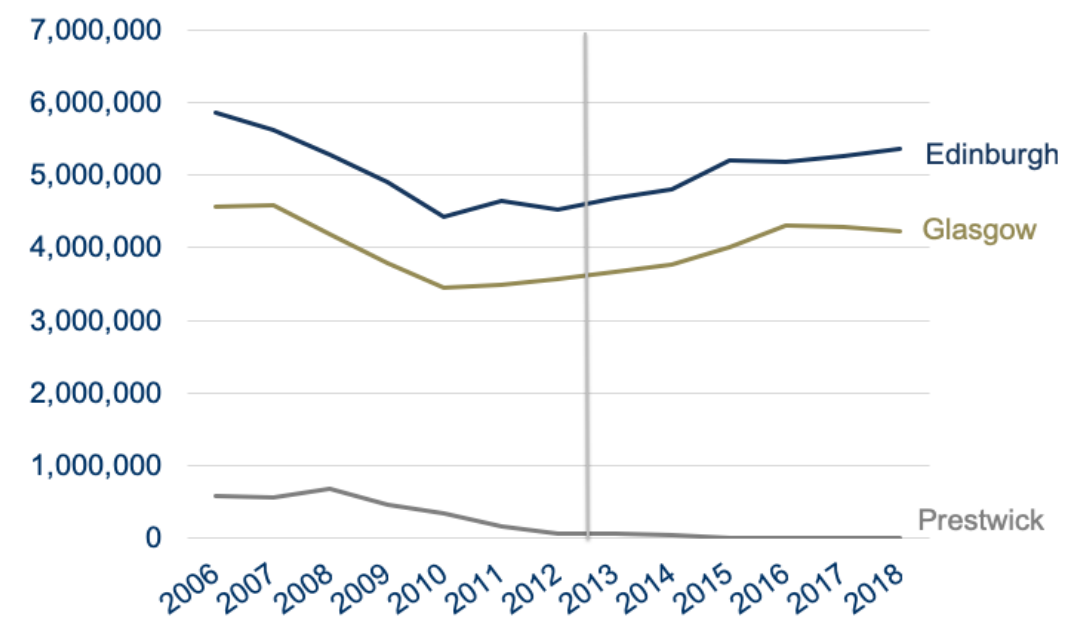

Source: CAA airport statistics 2006-2018 
However, this has been offset by much faster growth in international EU traffic, steadily at Edinburgh, and after the economic recession at Glasgow (albeit that there was a slight decline in 2018). By contrast Prestwick has seen a continuous decline in this type of traffic. One of the most dramatic changes has been the growth in nonEU traffic at Edinburgh, eclipsing Glasgow in 2016 as the gateway of choice for this market segment. Prestwick has now lost all its non-EU traffic (Figure 9 and 10).

Figure 9: EU terminal passengers at Edinburgh,

\section{Glasgow and Prestwick airport 2006-2017}

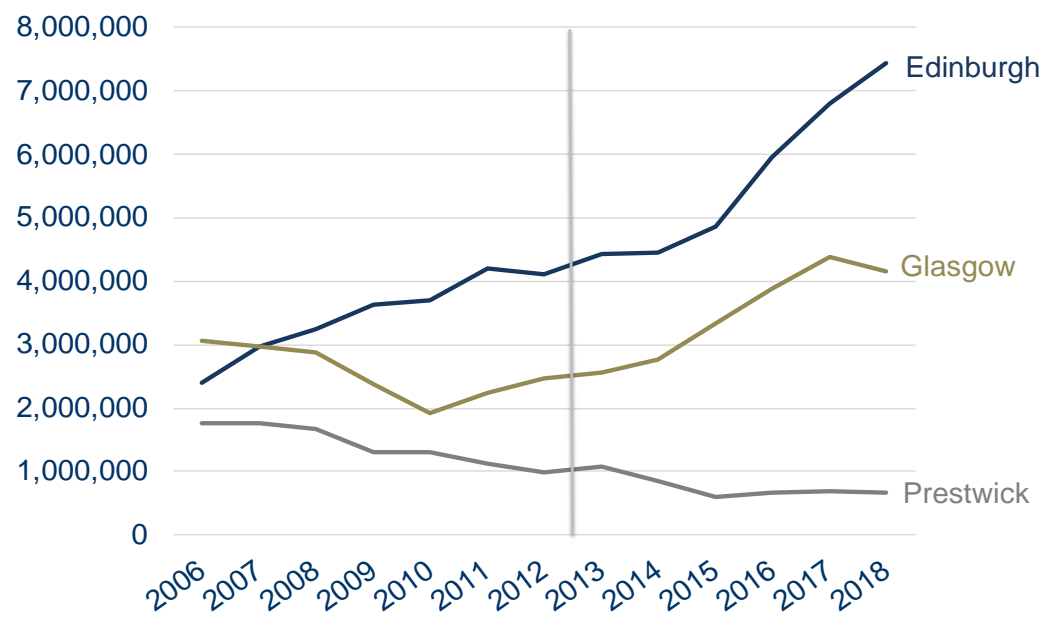

Source: CAA airport statistics 2006-2018

Figure 10: Non-EU terminal passengers at Edinburgh, Glasgow and Prestwick airport 2006-2018

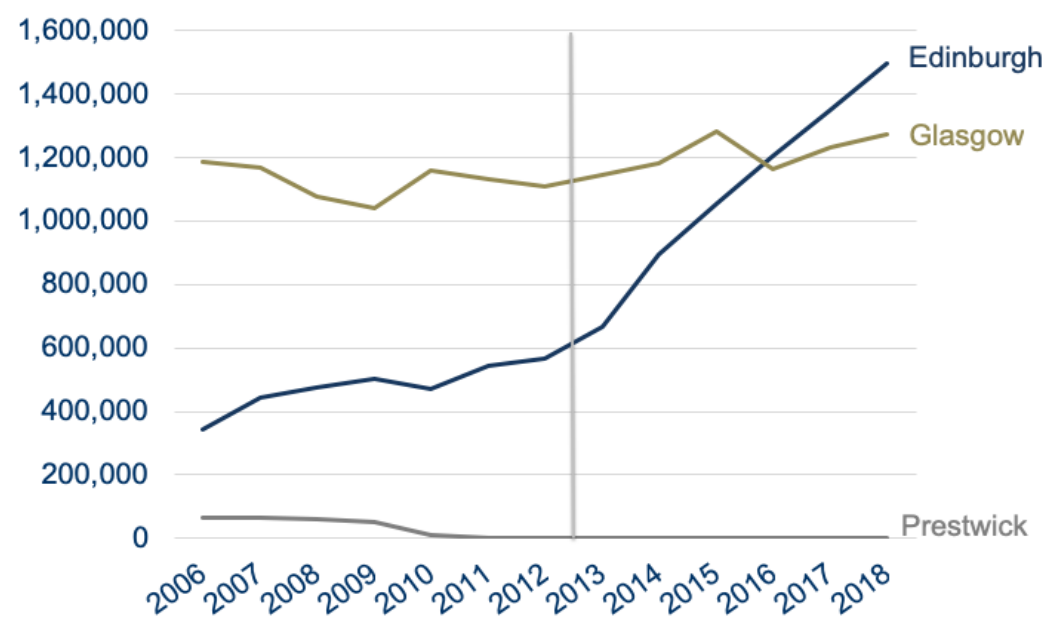

Source: CAA airport statistics 2006-2018

\subsection{Route development}


Figure 11 which shows the number of routes served by the three airports between 2006 and 2018 broadly mirrors growth trends also observed with regard to passenger traffic. Edinburgh has overtaken Glasgow in terms of the total number of routes. In 2018 it served 144 compared with 115 at Glasgow.

Figure 11: Total routes at Edinburgh, Glasgow and

Prestwick airport 2006-2018

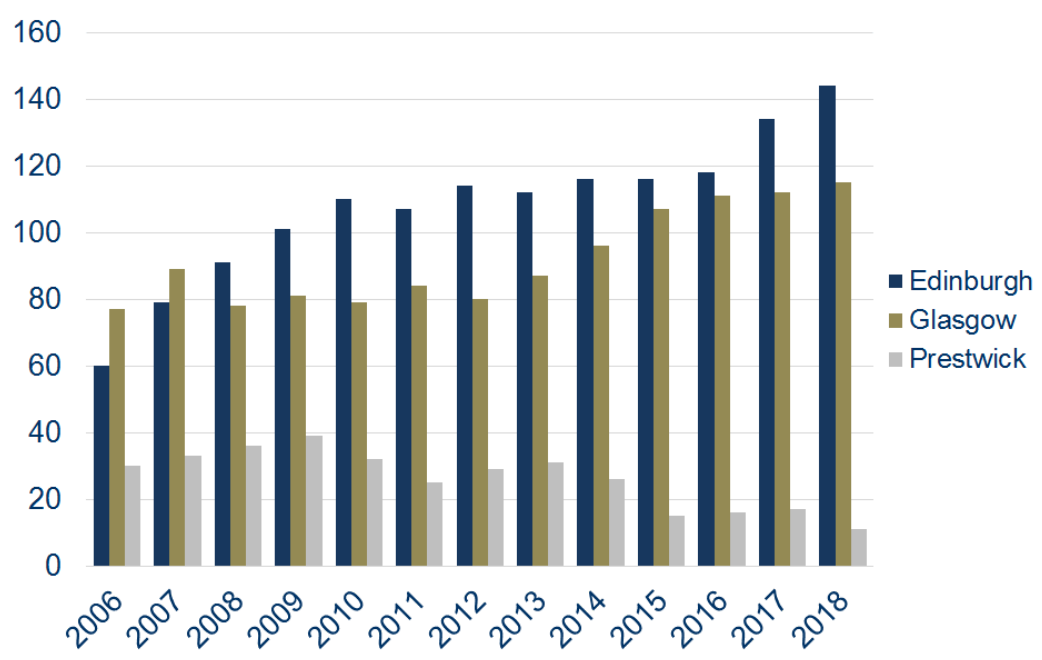

Source: Flight Global OAG Analyzer

The number of routes at Prestwick has declined from 30 in 2006 to only 11 in 2018. However, it is important to note that this only covers scheduled traffic but not charter flights. At Edinburgh, the charter market is insignificant as in $2006,96 \%$ of traffic was carried on scheduled services, this had increased to $98 \%$ by 2017 . In contrast, charter operations have always accounted for a higher proportion of traffic at Glasgow (9\% in 2017) - although there has been a marked decline in this market segment's share of traffic from a level of $22 \%$ in 2006 . The demise of charter operations is a phenomenon common to many other markets where there has been a significant loss of market share to LCCs.

Growth in the number of routes served is not necessarily a reflection of the effects of increased competition. One approach is to calculate 'route churn', i.e. the number of air carrier route entry and exists at each airport for a given year. Figure 12 shows that there was a considerable level of route churn at the three airports between 2006 and2018, suggesting competitive pressures, but there is no overall apparent trend that could indicate whether these pressures had increased or decreased over the years. Edinburgh airport was primarily responsible for the notably high levels of new 
routes in 2007 and 2017, whereas Prestwick experienced more losses of routes than the other airports in 2010 and 2015 when route closures were the most significant.

Figure 12: Route Churn (entry and exit of routes) at Edinburgh, Glasgow and Prestwick airport 2006-2018

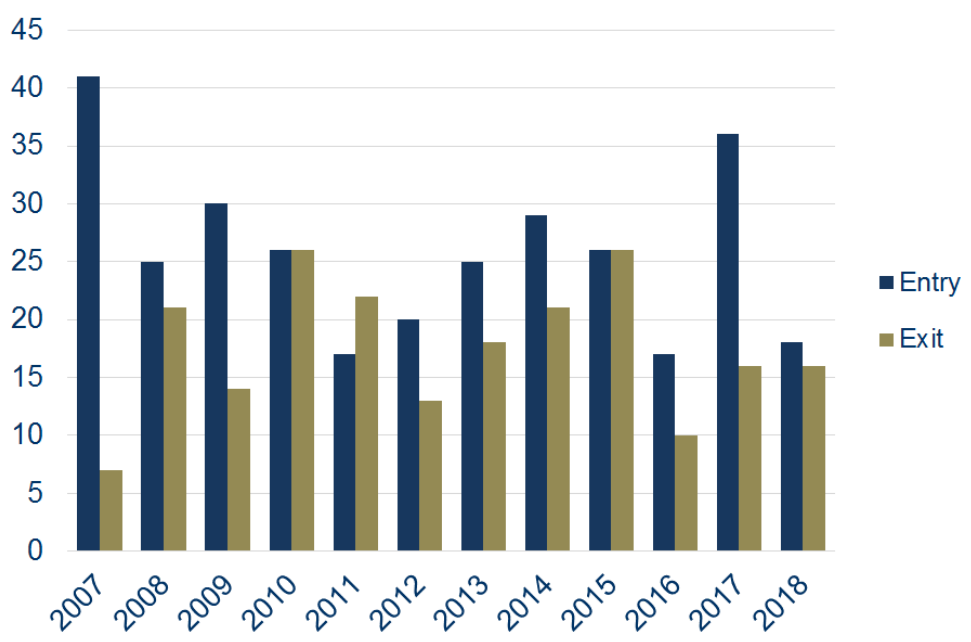

Source: Flight Global OAG Analyzer

Thirty-two routes were served by both Glasgow and Edinburgh in 2006. By 2018 an additional 24 routes were shared by both airports. Increased duplication of destinations by the two airports could arguably be interpreted as a reflection of heightened competitive intensity. Interestingly in 2006, Prestwick and Glasgow shared six routes and by 2018 this has increased to eight.

Both Edinburgh and Glasgow airports have respective entries in the webpages of the marketing website 'The Route Shop' which lists potential new routes that could be served. Given that Prestwick has lost many routes in recent years, it is not surprising that it identifies the largest number of routes (22) that could be served. Most of these are within Europe or Turkey but included on the list is also Boston and Orlando, demonstrating an ambition to once again serve the transatlantic market. Glasgow lists 10 routes, three of which are links to destinations in China. Similarly, amongst the 19 target routes identified by Edinburgh, three are in China with a further five proposals to link with airports located in other East Asian states. Overall only three of the routes are in Europe, indicating an ambition to expand further in the non-EU market segment. Several target routes have been listed by more than one airport (Boston, Brussels, Copenhagen, Hong Kong, Istanbul, Madrid, Orlando, Shanghai 
and Stockholm), suggesting the ability of these airports to potentially compete for services to these destinations.

Table 4: Routes unserved shown on 'The Route Shop’

\begin{tabular}{lll}
\hline Edinburgh airport $\left(^{*}\right)$ & Glasgow airport & Prestwick airport \\
\hline 19 routes & 10 routes & 22 routes \\
Bangkok, Bergen, Boston, Bremen, & Beijing, Boston, Brussels, & Belfast, Boston, Brussels, \\
Bridgetown, Bucharest, Delhi, & Copenhagen, Hamburg, Hong & Copenhagen, Cork, Dalaman, \\
Guangzhou, Hannover, Hong & Kong, Istanbul, Madrid, Shanghai, & Dusseldorf, Frankfurt, Geneva, \\
Kong, Las Vegas, Los Angeles, & Stockholm. & Gothenburg, Istanbul, Lisbon, \\
Luxembourg, Moscow, Mumbai, & & London, Madrid, Munich, Orlando, \\
Orlando, San Francisco, Shanghai, & & Oslo Paris, Prague, Southampton, \\
Tokyo. & & Stockholm, Zurich.
\end{tabular}

(*) Edinburgh airport also identifies two underserved routes, Vienna and Zurich

Source: The Route Shop (2019)

\subsection{Catchment area traffic}

The three airports attract passengers from many regions in Scotland, the majority originating from the Lowlands. Edinburgh airport arguably enjoys some accessibility advantages over its rivals. Being located to the west of the City Centre, makes it closer and more accessible to markets to the West of the lowlands such as Glasgow and its metropolitan region (see Figure 1). In contrast, Glasgow airport is located to the west of Glasgow City Centre making it less accessible to residents of Edinburgh and East-Central Scotland.

Catchment area statistics have been obtained for the time period under consideration (2009 and 2013) but only for Edinburgh and Glasgow. The top ten regions that generated the most traffic in 2013 were the City of Edinburgh, Glasgow City, Fife, South Lanarkshire, West Lothian, Renfrewshire, North Lanarkshire, Perth and Kinross, Stirling and Dundee City. Edinburgh's market share for all these regions increased between 2009 and 2013 (with the exception of West Lothian) tentatively suggesting that one of the reasons for Edinburgh's superior growth performance in recent years has been its ability to attract residents that traditionally preferred to fly from Glasgow (Table 5). 
Table 5: Top ten regions served by Edinburgh/Glasgow 2013 and

\begin{tabular}{|c|c|c|c|c|c|}
\hline $\begin{array}{l}\text { Scheduled passenger } \\
\text { numbers }(x 000) \text { by } \\
\text { region }\end{array}$ & $\begin{array}{l}\text { Edinburgh } \\
2013\end{array}$ & $\begin{array}{l}\text { Glasgow } \\
2013\end{array}$ & $\begin{array}{l}\text { Total } \\
2013\end{array}$ & $\begin{array}{l}\text { Edinburgh } \\
\text { Market } \\
\text { Share (\%) } \\
2009\end{array}$ & $\begin{array}{l}\text { Edinburgh } \\
\text { Market } \\
\text { Share (\%) } \\
2013\end{array}$ \\
\hline City of Edinburgh & 4,761 & 120 & 4881 & 95 & 98 \\
\hline Glasgow City & 362 & 2,153 & 2515 & 7 & 14 \\
\hline Fife & 963 & 70 & 1033 & 89 & 93 \\
\hline South Lanarkshire & 126 & 493 & 619 & 18 & 20 \\
\hline West Lothian & 446 & 65 & 511 & 91 & 87 \\
\hline Renfrewshire & 31 & 461 & 492 & 2 & 6 \\
\hline North Lanarkshire & 121 & 333 & 454 & 23 & 27 \\
\hline Perth and Kinross & 360 & 71 & 431 & 77 & 84 \\
\hline Stirling & 253 & 111 & 364 & 63 & 70 \\
\hline Dundee City & 276 & 71 & 347 & 73 & 80 \\
\hline
\end{tabular}

arket share 2009/2013

Source: CAA passenger survey report 2009 and 2013 (the 2018 report does not contain this data)

\section{Discussion}

Undoubtedly there have been some interesting developments in relation to the aeronautical charging strategies that have been adopted by the three Scottish airports. To some extent, these strategies relate to common ownership under BAA and the subsequent divestiture of Edinburgh airport. Common ownership ensured that there was consistency and uniformity in the published charges levied by both Edinburgh and Glasgow. During the period 2006-2012 BAA ensured that year-onyear real terms reductions in charge levels were achieved. This may not have been entirely commercially-driven in the sense that BAA appeared to be deliberately lowering the risk of regulatory price control intervention through imposing on itself a voluntary price-cap of RPI-3\% on average aeronautical yield (Competition Commission, 2009). 
Following the sale of Edinburgh airport, charging strategies did change indicating the presence of stronger competitive forces. Published charges increased at both Edinburgh and Glasgow, which seems counter-intuitive as in a more competitive environment one would have expected them to be lower. However, charges at Edinburgh (particularly those that were passenger-related) rose more rapidly than at Glasgow. This may well reflect the airport's intention, once separated from common ownership, to seize the opportunity to re-set its pricing strategy with reference to underlying market conditions where lower price-sensitivity (see the discussion below) limits the risk of losing market share to Glasgow. Meanwhile at Glasgow airport published charges also increased but not at the same rate as Edinburgh. This could indicate that as Prestwick's business prospects had deteriorated post-2008, diminishing its competitive threat, Glasgow seized an opportunity to its raise aeronautical charges. Another interpretation of this is simply that charges increased after 2012 as both airports were no longer bound by the voluntary price-cap. If accepted, this argument gives credibility to the airline industry's argument that economic regulation of airports is justified and needed (IATA, 2013) in contrast to ACl-Europe's opinion that is not necessary (ACl-Europe, 2017).

Aeronautical yield provides an additional insight into pricing strategy in that although published charges were rising at Glasgow, yield had declined, which perhaps reflects the impact of discounting effects where, unlike at Edinburgh, there are weaker market conditions and more price-sensitive traffic. Unfortunately, a knowledge gap exists for Prestwick airport as it is difficult to really assess its aeronautical charging because of the negotiated contract with its main customer Ryanair and the different mix of traffic in any yield calculation. Nevertheless, the limited evidence available does suggest that charges at Prestwick were and still are the lowest of all the three airports which is what would be expected given weaker business prospects relative to its larger competitors.

In terms of service quality, it is difficult to draw firm conclusions once again because of the limited evidence that is available. Generally, satisfaction rates improved during the period, which could well reflect a more competitive environment with airports enhancing service levels in order to attract more airlines and passengers. One important aspect of measuring service quality is that there may be a lag-effect in any analysis since passenger satisfaction rates may decline during phases of capital construction and refurbishment in advance of new facilities becoming operational. Indeed ICF (2016) noted that at Edinburgh there was a decline in passenger 
satisfaction rates in both 2013 and 2014 due capital investment short-term effects on service delivery.

With regards to traffic development, whilst there is a considerable overlap in the catchment areas served by the airports, Edinburgh in particular serves a very different core market compared to Glasgow and Prestwick. In addition to functioning as the administrative and political capital of Scotland, Edinburgh is also a significant centre for banking and finance, and possesses several internationally recognised and popular tourist attractions. In 2013 (the last year data is available), 31\% of its passenger market was business-related, which represented the highest share of any UK airport with the exception of London City (56\%) and Aberdeen (61\%). Forty per cent of its international leisure traffic was inbound which again was unusually high for a UK regional airport (CAA, 2014).

By contrast, in terms of air travel propensity, Glasgow airport has a weaker catchment area, with the region having traditionally depended on heavy industries and the manufacturing sector for much of its wealth. With the decline of many of these economic activities, the area has been left with higher than average unemployment and lower than average disposable income. As a consequence it is more dependent than Edinburgh on leisure traffic and LCC operations, and in 2013, outbound leisure travel represented $77 \%$ of its traffic. In 2009, Prestwick had the lowest share of business traffic $(8 \%)$ with a more proportionally significant inbound leisure travel dependency than Glasgow, representing half its outbound figure (CAA 2010, 2014). Prior to the 2008 financial crisis, the main carrier Ryanair which was in effect the sole operator at Prestwick offering a range of destinations both to secondary airports in key European metropolitan areas and traditional short-haul Mediterranean holiday destinations. Ryanair's retrenchment at Prestwick, which was part of a wider network strategy to migrate operations to primary airports, led to the loss of several connections leaving in 2018 a very limited range of seasonal services to holiday destinations.

Under common ownership, it has been claimed that BAA managed both airports as differentiated products offering Edinburgh as a business-focussed airport while Glasgow was presented as a predominantly leisure market facility. As such little effort was made to develop any form of competitive intensity between the two (CMA, 2016). By contrast Prestwick and Glasgow have always been considered much more as direct competitors in recent years, largely due to Ryanair's expansion of its Prestwick base which it opened in 1997. Passenger volumes at Prestwick peaked at 
above two million passengers between 2005 and 2008. Although Prestwick is disadvantaged in terms of its distance from key population concentrations, this was to some extent offset by the availability of a direct rail connection; its smaller size and lower airport costs' these being important features which initially attracted Ryanair to serving the airport (Pagliari, 2005).

The traffic analysis from 2006 shows that overall passenger numbers were affected by the economic recession of 2008-2009, but the impact was less pronounced at Edinburgh compared to Glasgow. This could well be due to Edinburgh's lesser dependence on the outbound leisure passenger segment. There was also a terrorist attack at Glasgow airport in 2007 which might have temporarily dampened traffic flows. Consequently, after this period the overall traffic levels at both Edinburgh and Glasgow have increased significantly, tentatively suggesting a strengthening of the competitive forces between them.

Meanwhile Prestwick's traffic has followed a virtually continuous downward trend in recent years with no domestic services and just a small number of EU connections remaining. Significantly in 2014, Ryanair opened a Glasgow base with the launch of seven routes, in line with its practice elsewhere of moving into larger airports. This followed other airlines, such as Wizz, who shifted services from Prestwick in 2013. With less than $3 \%$ overall market share and only around 10 routes left, Prestwick's ability to compete with the other airports appears to have weakened considerably.

Pricing trends observed at Edinburgh and Glasgow suggests that the airports have recognised the significant differences in price elasticities that exist in their respective markets. It appears that the sizeable charge increases at Edinburgh have had no evident impact on the robust and sustained traffic growth than has been observed there since 2012, suggesting that the airlines are willing to pay higher charges for the market advantages that Edinburgh offers, rather than using the cheaper Glasgow airport. Interestingly, in February 2018 Ryanair announced that it was transferring most of its Glasgow services to the more expensive Edinburgh airport for winter 2019 (although no information is available concerning the deal that has been agreed), while still maintaining limited operations from Glasgow (and Prestwick). The main reason for this shift the airline claimed was the high cost of the air passenger duty tax, although this still has to be paid on routes flying from Edinburgh (anna.aero, 2017). This means that it joined other LCCs such as Norwegian, Germanwings, Transavia and Vueling who decided to use Edinburgh as their preferred airport. This loss of routes for part of the year may partly explain the slight drop in Glasgow traffic 
in 2018. However, Ryanair announced in November 2018 that it would be reinstating in 2019 four of the 20 routes out of Glasgow Airport which it had cut adding to the three routes remaining. This clearly demonstrates the fluid competitive situation that exists between the two airports. The migration to Edinburgh is a reflection of the fact that many airlines, because of the nature of the market and the characteristics of the core catchment area attracted to Edinburgh, may be able to generate higher air fare yields compared to operating from Glasgow.

The increase in non-EU passengers and long-haul routes at Edinburgh could be interpreted as Edinburgh becoming more competitive in markets not previously considered by the airport during common ownership, where its business proposition was centred around functioning as a short-haul business-travel airport. New ownership has offered opportunities to develop a more diverse network serving both leisure and business markets. It had just one long-haul route in 2006. This compares to 2019, where the airport is connected to several long-haul destinations. For example, the new routes opened in 2018 included: Beijing, Dubai, Chicago and Philadelphia. However, this long-haul centred strategy has not been welcomed by all its airline customers, as the airport has been criticised by both its short-haul regional carriers Flybe and Loganair for being too focused on long-haul operations at the expense of domestic flights operated by smaller aircraft (Dalton, 2018).

\section{Conclusions}

In summary, it was the aim of this paper to undertake an assessment of airport competition within the Scottish Lowlands region and to examine whether competitive forces have been strengthening or weakening in recent years. Overall the analysis shows that since ownership separation, competition has intensified between Edinburgh and Glasgow, whilst Prestwick airport, which benefitted from Ryanair expansion in the 1990s, is now a significantly diminished competitive proposition in the Scottish Lowland market.

It is clear that at the beginning of the time period under consideration competition between Prestwick and Glasgow airport appeared quite strong, but the competitive forces between Glasgow and Edinburgh had been hindered by common ownership, albeit that there was still a considerable amount of route development and route churn taking place. However, it now appears that competition offered by Prestwick is quite minimal with the airport holding a very small market share. By contrast the competitive forces between Glasgow and Edinburgh seem to have been significantly 
strengthened, which is illustrated by not only a change in charging strategies but also by evidence suggesting that the airports are now seeking to appeal to the same markets rather than different segments, there are more shared routes, and some traffic from certain catchment areas seems to have shifted. Service quality at the two airports also appears to be improving. These findings may have implications for the development of regulatory policy. More specifically how competitive airport markets function and the potential impact of ownership change on commercial behaviour and pricing strategy. Ownership change appears to have led to price divergence rather than lower charges which is in contrast to the expectations of policy makers when the Competition Commission concluded its examination of market power in the UK airport sector.

Limitations within this analysis need to be recognised. The datasets, particularly related to areas such as service quality, passenger characteristics and catchment areas, are incomplete or somewhat dated, and overall the time series under consideration is relatively short. As a result, it has not been possible to undertake a more developed econometric approach to quantitatively assess the existence of competition. Moreover, greater insight could have been gained with primary research, as well as this secondary analysis, by consulting with some of the key stakeholders involved, particularly the airport operators and airlines, to hear their interpretation of some of the evidence gathered here. In fact a series of semistructured interviews, with stakeholders involved - including passengers - would add to the knowledge base here. Greater understanding about the situation at Prestwick would be very useful.

An area where no conclusions can be drawn at present is the impact of the change of ownership of Glasgow from HAH to AGS, especially as this is a relatively recent development. Hence whilst this research has made a considerable and unique contribution to understanding the competitive forces between airports within the Scottish Lowlands region, there is certainly an opportunity for further research in the future.

\section{Acknowledgements}

The authors would like to thank Mr Francois Bourienne, Director Commercial, Glasgow Airport Ltd for his very valuable insights on aeronautical charging, route development and airport competition.

\section{References}


ACl-Europe (2014), Competition in the European Aviation Sector, Brussels: ACIEurope.

ACl-Europe (2017), The Competitive Edge: Airports in Europe, Brussels: ACIEurope.

anna.aero (2018), Ryanair calls time on Glasgow where it is currently the third biggest airline; more than one aircraft being lost as 19 routes are poised to close, anna.aero, 1 March. Available at https://www.anna.aero/2018/03/01/ryanairsglasgow-base-closure/ (accessed 10 January 2019).

Auditor General (2015), The Scottish Government's purchase of Glasgow Prestwick Airport, Edinburgh: Audit Scotland

Barrett, S. (2000), Airport competition in the deregulated European aviation market, Journal of Air Transport Management, 6(1), 13-22.

Bel, G. and Fageda, X. (2010), Privatization, regulation, and airport pricing: an empirical analysis for Europe, Journal of Regulatory Economics, 37, 142 - 161.

Bel, G. and Fageda, X. (2013), Market power, competition and post-privatization regulation: Evidence from changes in regulation of European airports, Journal of Economic Policy Reform, 16(2), 123-141.

BBC (2014), Aberdeen, Glasgow and Southampton airports sold in £1bn deal, BBC, 16 October. Available at https://www.bbc.co.uk/news/uk-scotland-29650438 (accessed 10 January 2019)

Bottasso, A., Bruno, M., Conti, M. and Piga, C. (2017), Competition, vertical relationship and countervailing power in the UK airport industry, Journal of Regulatory Economics, 52(1), 37-62.

Bush, H. (2009), The development of competition in the UK airport market, Journal of Airport Management, 4(2), 114-24.

Bush, H. and Starkie, D. (2014),Competitive drivers towards improved airport/airline relationships, Journal or Air Transport Management, 41, 45-49.

CAA (2005), UK Regional Air Services, CAP 754. London: CAA. 
CAA (2007), Air Services at UK Regional Airports: An Update on Developments, CAP 775, London: CAA.

CAA (2011), Guidance on the Assessment of Airport Market Power, London: CAA. CAA (2019) 2018 Passenger Survey Report, London: CAA.

Competition and Markets Authority (2016), BAA airports: Evaluation of the Competition Commission's 2009 market investigation remedies, London: CMA.

Competition Commission (2009), BAA Airports Market Investigation, London: Competition Commission.

Dalton, A. (2018), Flybe chief slams Edinburgh Airport's 'appalling service, The Scotsman, 13 October. Available at https://www.scotsman.com/news/flybe-chiefslams-edinburgh-airport-s-appalling-service-1-4814687 (accessed 10 January 2019).

De Wit, J. and Zuidberg, J. (2016), Route churn: an analysis of low-cost carrier route continuity in Europe, Journal of Transport Geography, 50, 57-67.

Department for Transport (2018), One giant leap: Vertical launch spaceport to bring UK into new space age, Department for Transport, press release 15 July. Available at https://www.gov.uk/government/news/one-giant-leap-vertical-launch-spaceport-tobring-uk-into-new-space-age (accessed 10 January 2019).

Fichert, F. (2019), The airline-airport relationship: Allocating risks and opportunities in a vertical partnership, in Graham, A. and Dobruszkes, F. (eds) Air Transport: A Tourism Perspective, Oxford: Elsevier.

Forsyth, P. (2006), Airport competition: regulatory issues and policy implications, in Lee, D. (ed.), Competition Policy and Anti-Trust, Oxford: Elsevier.

Forsyth, P., Gillen, D., Mueller, J. and Niemeier, H.-M. (eds) (2010), Airport Competition, Abingdon: Routledge.

Garrow, L.(2010), Discrete Choice Modelling and Air Travel Demand: Theory and Application. Farnham: Ashgate.

Gillen D. and Law, A. (2004), Competitive advantage of low-cost carriers: some implications for Airports, Journal of Airport Management, 10(1), 41-50. 
Graham, A. (2006), Competition in airports, in Papatheodorou, A. (ed.), Corporate Rivalry and Market Power: Competition Issues in the Tourism Industry, London: I.B. Tauris.

Graham, A. (2013), Understanding the low cost carrier and airport relationship: A critical analysis of the salient issues, Tourism Management, 36, 66-76.

Halpern, N. and Graham, A. (2013), Airport Marketing, Abingdon: Routledge.

Halpern, N., Graham, A., and Dennis, N. (2016), Low cost carriers and the changing fortunes of airports in the UK. Research in Transportation Business and Management, 21, 33-43.

Hess, S., Adler, T. and Polak, J.W. (2007), Modelling airport and airline choice behaviour with the use of stated preference survey data, Transportation Research Part E: Logistics and Transportation Review, 43(3), 221-233.

Huderek-Glapska, S. and Nowak, H. (2016), Airport and low cost carrier business relationship management as a key factor for airport continuity: the evidence from Poland, Research in Transportation Business and Management, 21, 44-53.

Humphreys, I. (1999), 'Privatisation and commercialisation changes in UK airport ownership patterns', Journal of Transport Geography, 7(2): 121-34.

Humphreys, I., Ison, S. and Francis, G. (2005), A review of the airport-low cost airline relationship, Review of Network Economics, 17(5), 413-420.

IATA (2013), Airport Competition, IATA Economics Briefing No 11, Geneva: IATA.

ICF (2016), Evaluation of the 2009 Competition Commission's BAA airports market investigation remedies, London: ICF.

Ison, S., Francis, G., Humphreys, I., and Page, R. (2011), UK regional airport commercialisation and privatisation: 25 years on, Journal of Transport Geography, 19(6), 1341-1349.

Jankovic, O. (2018), State of the industry address. ACI Airport Exchange 2018, November, Oslo. 
Jones, O., Budd, L. and Pitfield, D. (2013), Aeronautical charging policy incentive schemes for airlines at European airports, Journal of Air Transport Management, 33, 43-59.

Lei, Z., and Pagliari, R. (2013), Airport traffic growth and airport financial performance. in Forsyth, P., Gillen D., Hüschelrath, K., Niemeier, H.-M. and Wolf, W. (eds.), Liberalization in aviation. Abingdon: Routledge.

LeighFisher (2012), Comparing and Capping Airport Charges, London: LeighFisher.

Lieshout, R. (2012), Measuring the size of an airport's catchment area. Journal of Transport Geography, 25, 27-34.

Lieshout, R., Malighetti, P., Redondi, R., and Burghouwt, G. (2016), The competitive landscape of air transport in Europe, Journal of Transport Geography, 50, 68-82.

Littlechild, S. (2018), Economic regulation of privatised airports: Some lessons from UK experience. Transportation Research Part A: Policy and Practice, 114, 100-114.

Kim, M. H., Park, J. W., and Choi, Y. J. (2016), A study on the effect of airport choice attributes on airport users' satisfaction and behavioural intentions: The case of Gimpo international airport. Journal of Airport Management, 10(2), 145-157.

Malina, R., Albers, S. and Kroll, N. (2012), Airport incentive programmes: a European perspective, Transport Reviews, 32(4), 435-53.

Mohammed, A. and Roisman, R. (2017), 2015 Washington-Baltimore Regional Air Passenger Survey, Washington DC: The National Capital Region Transportation Planning Board.

OECD (2014), Expanding Airport Capacity: Competition and Connectivity, Paris: OECD.

Oxera (2017), The Continuing Development of Airport Competition in Europe, London: Oxera.

Pagliari, R., (2005), Developments in the supply of direct international air services from airports in Scotland, Journal of Air Transport Management, 11(4), 249-257. 
Pantazis, N. and Liefner, I. (2006), The impact of low-cost carriers on catchment areas of established international airports: the case of Hanover airport, Germany, Journal of Transport Geography, 14(4): 265-72.

Papatheodorou, A. and Lei, Z. (2006), Leisure travel in Europe and airline business models: A study of regional airports in Great Britain', Journal of Air Transport Management, 12(1), 47-52.

Prentice, C., and Kadan, M. (2019), The role of airport service quality in airport and destination choice, Journal of Retailing and Consumer Services, 47, 40-48.

Ryerson, M.S. (2017), Incenitvize it and they will come? How some of the busiest U.S. airports are building air service with incentive programs, Journal of American Planning Association, 82(4), 303-315.

Socorro, M., Betancor, O. and de Rus, G., (2018), Feasibility and desirability of airport competition: The role of product substitutability and airlines' nationality. Journal of Air Transport Management, 67, 224-231.

Starkie D. (2008), The Airport Industry in a Competitive Environment: A United Kingdom Perspective, Discussion paper No 2005-15, Paris, International Transport Forum.

Starkie, D. (2012), European airports and airlines: evolving relationships and the regulatory implications, Journal of Air Transport Management, 21, 40-49.

Thelle, M., Pedersen, T. and Harhoff, F. (2012), Airport Competition in Europe, Copenhagen: Copenhagen Economics.

Thelle, M. and Sonne, M. (2018), Airport competition in Europe, Journal of Air Transport Management, 67, 232-240.

Van Dender, K. (2007), Determinants of fares and operating revenues at US airports, Journal of Urban Economics, 62(2), 317-336.

Which? (2019a), Best and worst large UK airports. Available at https://www.which.co.uk/reviews/airports/article/uk-airports/best-and-worst-large-ukairports (accessed 12 January 2019). 
Which? (2019b), Best and worst small UK airports. Available at https://www.which.co.uk/reviews/airports/article/uk-airports/best-and-worst-small-ukairports (accessed 12 January 2019).

Wiltshire, J. (2018), Airport competition: Reality or myth? Journal of Air Transport Management, 67, 241-248. 